\title{
Peran Dukungan Sosial Orang Tua terhadap Prestasi Akademis melalui Mediasi Motivasi Belajar Intrinsik
}

\author{
Sabrina Annisa Mauliddya ${ }^{1}$ E Amrizal Rustam ${ }^{2}$ \\ 1,2Fakultas Psikologi Universitas Gadjah Mada
}

\begin{abstract}
This research aimed to empirically examine the effect of parents' social support on academic achievement through the mediation of intrinsic motivation to learn. It was hypothesized that parents' social support positively affect academic achievement through the mediation of intrinsic motivation to learn. Researcher adapted Gordon's Parent Subscale Social Support Questionnaire for Children Rahmi's Parental Support Scale and Rahmi's Intrinsic Motivation to Learn Subscale along with weighted summative asessment tests to measure academic achievement. Participants were 84 students of grade 8 from three different junior high schools in Yogyakarta. Path analysis was used to investigate the hyphotesis. Results indicated that parents' social support was a significant predictor of intrinsic motivation to learn, $b=0.55,(p<0.05)$, and that intrinsic motivation to learn was a significant predictor of academic achievement, $b=0.47,(p<0.05)$. These results supported the mediational hypothesis. Parents' social support was no longer a significant predictor of academic achievement after including the mediator, parents' social support, $b=0.16,(p>$ 0.05), consistent with full mediation.
\end{abstract}

Keywords : academic achievement; intrinsic motivation to learn; parents' social support

Abstrak. Penelitian ini bertujuan untuk menguji secara empiris pengaruh dukungan sosial orang tua terhadap prestasi akademis melalui mediasi motivasi belajar intrinsik. Hipotesis yang diajukan dalam penelitian ini adalah dukungan sosial orang tua berpengaruh positif terhadap prestasi akademis melalui mediasi motivasi belajar intrinsik. Peneliti mengadaptasi Parent Subscale Social Support Questionnaire for Children yang digunakan oleh Gordon, Skala Dukungan Orang Tua dan Subskala Motivasi Belajar Intrinsik yang digunakan oleh Rahmi, serta menggunakan hasil tes sumatif yang dibobot untuk mengukur prestasi akademis. Subjek dalam penelitian ini adalah 84 siswa kelas 8 dari tiga sekolah menengah pertama (SMP) di Yogyakarta. Analisis jalur digunakan untuk menguji hipotesis. Hasil menunjukkan dukungan sosial orang tua merupakan prediktor signifikan motivasi belajar intrinsik, $b=0,55(p<0,05)$, dan motivasi belajar intrinsik merupakan prediktor signifikan prestasi akademis, $b=0,47(p<0,05)$. Hasil tersebut mendukung hipotesis mediasi. Dukungan sosial orang tua tidak lagi menjadi prediktor signifikan prestasi akademis setelah menyertakan mediator, dukungan sosial orang tua, $b=0,16(p>0,05)$, konsisten dengan mediasi penuh.

Kata kunci : dukungan sosial orang tua; motivasi belajar intrinsik; prestasi akademis

Prestasi akademis merupakan salah satu fokus penting dalam bidang pendidikan

${ }^{1}$ Korespondensi mengenai artikel ini dapat dilakukan melalui mauliddyasabrina@gmail.com 2atau amrizal.rustam@ugm.ac.id
Prestasi akademis merujuk pada keberhasilan dalam area belajar yang dapat diidentifikasi; atau tingkat penguasaan dalam konteks umum maupun keterampilan khusus 
(VandenBos, 2015). Good (dalam Phye, 1997) mendefinisikan prestasi akademis sebagai pengetahuan yang diperoleh atau keterampilan yang dikembangkan dalam pelajaran di sekolah, yang diperoleh dari skor tes atau nilai dari guru, atau keduanya. Menurut Azwar (2014) instrumen yang digunakan untuk mengukur prestasi atau hasil yang telah dicapai siswa dalam belajar disebut tes prestasi akademis. Tes ini dapat berbentuk ulangan harian, tes formatif, tes sumatif, bahkan ebtanas dan ujian masuk perguruan tinggi. Azwar (2017) juga mengatakan bahwa prestasi atau keberhasilan belajar dapat dioperasionalisasikan dalam bentuk indikator-indikator berupa nilai rapor, indeks prestasi studi, angka kelulusan, predikat keberhasilan, dan semacamnya.

Asesmen prestasi akademis terus dilakukan di berbagai negara secara berkala, baik pada tingkat nasional maupun internasional. PISA (Programme for International Student Assessment) merupakan salah satu asesmen prestasi akademis pada tingkat internasional. Hasil PISA pada tahun 2015 menunjukkan dari 70 negara Indonesia berada pada peringkat 63 dengan skor rata-rata 403 dalam bidang sains, 397 dalam bidang literasi, dan 386 pada bidang matematika (Organisation for Economic Co-operation and Development [OECD], 2016). Selain PISA, asesmen prestasi akademis pada tingkat internasional adalah TIMSS (Trends in International Mathematics and Science Study) yang lebih spesifik mengases prestasi akademis pada bidang matematika dan sains. Hasil TIMSS pada tahun 2015 menunjukkan Indonesia pada bidang matematika berada pada peringkat 49 dari 54 negara yang mengikuti asesmen dengan skor rata-rata 397 dan pada bidang sains berada pada peringkat 51 dengan skor rata-rata 397 (International Association for the Evaluation of Educational
Achievement [IEA], 2016a, 2016b). Ini menunjukkan bahwa prestasi akademis Indonesia pada tingkat internasional berada pada peringkat bawah, dengan kata lain prestasi akademis di Indonesia termasuk dalam kategori rendah. Kondisi prestasi akademis di Indonesia yang berada pada kategori rendah tentu memprihatinkan mengingat prestasi akademis merupakan prediktor yang baik dalam mengukur keberhasilan belajar.

Menurut Azwar (2017) faktor-faktor yang dapat memengaruhi keberhasilan dalam belajar dapat dibagi menjadi dua, yaitu faktor internal atau yang berasal dari dalam diri individu seperti panca indra, kondisi fisik umum, minat, motivasi belajar, kepribadian, bakat, dan inteligensi, dan faktor eksternal atau yang berasal dari luar diri individu seperti kondisi lingkungan belajar, sarana dan perlengkapan belajar, materi pelajaran, dukungan sosial, dan pengaruh budaya. Dukungan sosial merupakan salah satu faktor yang dapat memengaruhi prestasi atau keberhasilan belajar. Dukungan sosial dapat berbentuk bantuan praktis seperti memberi nasihat, tangible support yang meliputi pemberian uang atau materi pelengkap, dan dukungan emosional yang membuat individu merasa dihargai, diterima, dan dimengerti (VandenBos, 2015).

Cobb (dalam Cutrona \& Russell, 1987) membagi dukungan sosial menjadi lima aspek, yaitu emotional support atau dukungan berupa rasa aman dan nyaman, network support atau dukungan berupa keanggotaan dari suatu kelompok yang terus berhubungan, esteem support atau dukungan berupa penghargaan dan pengakuan, material support atau dukungan berupa pemberian benda atau uang, dan instrumental support atau dukungan berupa bimbingan dan nasihat. Menurut Chen (dalam Li, 2012) dukungan sosial yang paling berpengaruh terhadap 
prestasi akademis dapat dibagi menjadi tiga, yaitu yang diperoleh dari orang tua atau disebut dukungan sosial orang tua, yang diperoleh dari guru atau disebut dukungan sosial guru, dan yang diperoleh dari teman sebaya atau disebut dukungan sosial teman sebaya. Salah satu faktor yang memengaruhi prestasi akademis yang banyak diteliti adalah dukungan sosial orang tua.

Penelitian mengenai hubungan antara dukungan sosial orang tua, kontrol perilaku, dan kontrol psikologis dengan prestasi akademis dan harga diri pada 75 siswa Afrika-Amerika dan 80 siswa Eropa-Amerika dari 6 sekolah menengah negeri di Midwest Amerika menunjukkan dukungan sosial orang tua secara signifikan memiliki hubungan yang positif dengan prestasi akademis siswa Afrika-Amerika (Bean, Bush, McKenry \& Wilson, 2003). Penelitian mengenai pengaruh keterlibatan orang tua, dukungan sosial orang tua, dan pendidikan keluarga terhadap prestasi akademis dan penyesuaian diri pada siswa prasekolah, sekolah dasar, dan sekolah menengah yang diambil dari 10 database dan 7 website di Britania Raya, Amerika Serikat, Australia, Selandia Baru, dan Skandinavia pun menunjukkan keterlibatan orang tua secara signifikan berpengaruh positif terhadap prestasi akademis (Desforges \& Abouchaar, 2003).

Penelitian serupa pun dilakukan di sebuah SMP negeri di Semarang, pada 99 siswa kelas 8, mengenai pengaruh dukungan sosial orang tua dan fasilitas belajar di sekolah terhadap prestasi akademis dengan motivasi belajar sebagai mediator. Hasil penelitian menunjukkan dukungan sosial orang tua berpengaruh secara signifikan terhadap motivasi belajar dan prestasi akademis siswa (Rahman, 2014).

Peneliti kemudian melakukan studi lapangan awal untuk mengetahui apakah fenomena yang terjadi di lapangan sesuai dengan yang tercantum dalam literatur. Studi lapangan awal dilakukan dalam bentuk wawancara terhadap tiga orang guru yang mengajar di tiga SMP Negeri di Kota Yogyakarta yang berada pada peringkat atas, sedang, dan bawah (SIAP PPDB Online, 2014; 2015; 2016) mengenai prestasi belajar siswa dan peran keterlibatan orang tua terhadap prestasi tersebut. Hasil wawancara menunjukkan sebagian besar siswa yang memperoleh prestasi akademis tinggi cenderung mendapat dukungan sosial orang tua yang tinggi pula. Hasil wawancara juga menunjukkan motivasi siswa dalam belajar dan berprestasi cenderung lebih terlihat ketika orang tua terlibat aktif dalam mendukung perkembangan belajar siswa. Inilah yang kemudian memungkinkan siswa memperoleh prestasi akademis yang lebih tinggi.

$$
\text { Faktor lain yang dapat }
$$

memengaruhi prestasi akademis adalah motivasi belajar. Motivasi merujuk pada sesuatu yang memberi tujuan atau mengarahkan perilaku dan bekerja di dalam kesadaran maupun ketidaksadaran manusia (VandenBos, 2015). Motivasi pada umumnya dibagi menjadi dua, yaitu motivasi intrinsik dan motivasi ekstrinsik. Motivasi intrinsik merupakan sesuatu yang mendorong seseorang untuk terlibat dalam suatu aktivitas khusus yang berasal dari kesenangan dalam aktivitas tersebut daripada keuntungan eksternal yang mungkin diperoleh, sementara motivasi ekstrinsik merupakan sesuatu yang mendorong seseorang untuk terlibat dalam suatu aktivitas khusus yang berasal dari harapan memperoleh reward (VandenBos, 2015). Menurut Ryan \& Deci (2000) motivasi intrinsik berasal dari dalam diri individu dan hubungan yang terjalin antara individu tersebut dengan aktivitas yang dilakukan sehingga motivasi intrinsik dapat dibagi menjadi 
tiga komponen, yaitu personal interest atau aktivitas yang dilakukan menarik, personal enjoyment atau aktivitas yang dilakukan menyenangkan, dan personal satisfaction atau aktivitas yang dilakukan memberi rasa puas. Ryan \& Deci (2000) juga mengatakan bahwa motivasi belajar yang lebih baik dalam memprediksi prestasi akademis adalah motivasi belajar intrinsik.

Penelitian mengenai hubungan antara motivasi belajar intrinsik dan kebahagiaan dengan prestasi akademis pada 341 siswa sekolah menengah atas di Abhar, Iran, menunjukkan bahwa terdapat hubungan yang positif antara motivasi belajar intrinsik dengan prestasi akademis siswa (Khosnam, Ghamari \& Gendavi, 2013). Penelitian mengenai hubungan antara motivasi belajar intrinsik dengan prestasi belajar pada siswa kelas 10 di sebuah sekolah menengah kejuruan (SMK) juga menunjukkan hasil serupa, yaitu terdapat hubungan yang positif antara motivasi belajar intrinsik dengan prestasi belajar (Ramida, Astuti \& Swaramarinda, 2014). Penelitian lain mengenai pengaruh dukungan sosial orang tua dan fasilitas belajar di sekolah terhadap prestasi akademis dengan motivasi belajar sebagai variabel mediator pada 99 siswa kelas 8 di sebuah SMP di Semarang juga menunjukkan motivasi belajar secara signifikan mampu memediasi pengaruh dukungan sosial orang tua terhadap prestasi akademis siswa.

Hasil studi literatur dan studi lapangan awal menunjukkan dukungan sosial orang tua dan motivasi belajar intrinsik berpengaruh positif terhadap prestasi akademis. Hasil studi juga menunjukkan dukungan sosial orang tua berpengaruh positif terhadap motivasi belajar siswa. Berdasarkan uraian di atas penelitian ini bertujuan untuk menguji secara empiris pengaruh dukungan sosial orang tua terhadap prestasi akademis melalui mediasi motivasi belajar intrinsik. Hipotesis yang diajukan adalah dukungan sosial orang tua berperan positif terhadap prestasi akademis melalui mediasi motivasi belajar intrinsik. Hasil penelitian ini diharapkan dapat mendukung upayaupaya di bidang pendidikan dan perkembangan belajar siswa agar motivasi belajar intrinsik dan prestasi akademis siswa dapat meningkat.

\section{Metode}

\section{Partisipan penelitian}

Partisipan dalam penelitian ini adalah siswa-siswi kelas 8 dari tiga SMP di Kota Yogyakarta berusia 12 hingga 15 tahun.. Jumlah total partisipan adalah 84 siswa (laki-laki sebanyak 34 orang dan perempuan sebanyak 50 orang). Sekolah negeri dipilih agar mewakili keberagaman etnis dan SES (Status Sosial Ekonomi) siswa. Selain itu, peneliti memilih ketiga sekolah tersebut karena masing-masing sekolah mewakili SMP Negeri di Kota Yogyakarta yang berada pada peringkat atas, sedang, dan bawah sehingga hasil penelitian dapat digeneralisasi lebih luas.

\section{Instrumen penelitian}

Prestasi akademis dalam penelitian ini diukur melalui tes sumatif atau UAS (Ujian Akhir Semester) tertulis semester genap tahun 2017 yang terdiri dari lima mata pelajaran Bahasa Indonesia sejumlah 50 soal, Matematika sejumlah 40 soal, Ilmu Pengetahuan Alam sejumlah 40 soal, Ilmu Pengetahuan Sosial sejumlah 50 soal, dan Bahasa Inggris sejumlah 50 soal, dalam bentuk soal pilihan ganda yang disusun oleh guru mata pelajaran dari masing-masing sekolah. Materi yang diujikan pada tes sumatif sama pada setiap sekolah sesuai dengan kompetensi dasar yang terdapat dalam Kurikulum Pendidikan SMP/MTs tahun 2013. Hasil 
tes sumatif tertulis pada lima mata pelajaran tersebut dibobot dengan rumus $[X=(b / n) \times 100]$ oleh masing-masing guru mata pelajaran sesuai jumlah pertanyaan; $X$ adalah nilai/skor tes yang telah dibobot, $b$ adalah pertanyaan yang dijawab dengan benar, dan $n$ adalah jumlah soal. Skor tes masing-masing mata pelajaran yang telah dibobot kemudian dijumlahkan.

Skala yang digunakan dalam mengukur dukungan sosial orang tua pada penelitian ini diadaptasi dari Parent Subscale Social Support Questionnaire for Children yang disusun oleh Gordon (2011) dan Skala Dukungan Orang Tua yang disusun oleh Rahmi (2011) dengan memperbaiki kalimat pada aitem skala tersebut dan menambah dan mengurangi aitem sesuai dengan teori yang digunakan dalam penelitian ini. Dukungan sosial orang tua dalam penelitian ini terdiri dari lima aspek, yaitu emotional support, network support, esteem support, material support, dan instrumental support. Skala ini terdiri dari 34 aitem, dan disajikan dalam bentuk tipe Likert yang terdiri dari lima kategori respon, yaitu SS (Sangat Sesuai), S (Sesuai), N (Netral), TS (Tidak Sesuai), dan STS (Sangat Tidak Sesuai). Koefisien reliabilitas alpha Cronbach skala sebesar 0,919 .

Skala yang digunakan dalam mengukur motivasi belajar intrinsik pada penelitian ini diadaptasi dari Subskala Motivasi Belajar Intrinsik yang disusun oleh Rahmi (2011). Motivasi intrinsik dalam penelitian ini terdiri dari tiga aspek, yaitu personal interest, personal

Tabel 1

Deskripsi Data enjoyment, dan personal satisfaction. Peneliti menambahkan aitem sesuai dengan teori yang digunakan dalam penelitian ini. Skala terdiri atas 52 aitem yang disajikan dalam bentuk Likert dan terdiri dari lima kategori respon, yaitu SS (Sangat Sesuai), S (Sesuai), N (Netral), TS (Tidak Sesuai), dan STS (Sangat Tidak Sesuai). Koefisien reliabilitas alpha Cronbach skala ini adalah 0,933 .

\section{Analisis data}

Analisis dilakukan menggunakan analisis mediasi Kim (2016) dengan tiga jalur regresi, yaitu jalur satu (X ke $Y)$, jalur dua ( $X$ ke $M)$, dan jalur tiga $(X+M$ ke $Y)$. Analisis regresi pada jalur tiga menunjukkan apakah terjadi full mediation, yaitu $\mathrm{M}$ memediasi pengaruh $\mathrm{X}$ terhadap $Y$ sepenuhnya sehingga pengaruh $X$ terhadap $\mathrm{Y}$ hilang atau partial mediation, yaitu $M$ memediasi sebagian pengaruh $X$ terhadap $Y$ sepenuhnya sehingga pengaruh $\mathrm{X}$ terhadap $\mathrm{Y}$ tetap ada namun berkurang.

\section{Hasil}

Deskripsi data

Melalui Tabel 1 dapat dilihat data deskriptif dari variabel-variabel yang diteliti. Rata-rata skor variabel dukungan sosial orang tua adalah 126,50 $(S D=$ $14,07)$. Rata-rata skor dari motivasi belajar intrinsik siswa adalah 172,24 $(S D=22,24)$. Sementara itu, rata-rata skor prestasi akademis siswa untuk lima mata pelajaran adalah $411,10(S D=12,70)$.

\begin{tabular}{lcccc}
\hline \multirow{2}{*}{ Variabel } & \multicolumn{4}{c}{ Empirik } \\
\cline { 2 - 5 } & Min & Maks & Mean & SD \\
\hline Dukungan Sosial Orang Tua (X) & 92 & 158 & 126,50 & 14,07 \\
Motivasi Belajar Intrinsik (M) & 126 & 230 & 172,24 & 22,24 \\
Prestasi Akademis (Y) & 384 & 441 & 411,10 & 12,70 \\
\hline
\end{tabular}

Keterangan: Min = skor minimum, Maks = skor maksimum, Mean = rata-rata, $\mathrm{SD}=$ standar deviasi 
Uji asumsi

Sebelum melakukan uji regresi dengan model tiga jalur, terdapat dua uji asumsi yang harus dipenuhi yaitu uji normalitas dan uji linearitas. Tabel 2 menunjukkan bahwa data masing-masing variabel penelitian terdistribusi dengan normal. Setelah melakukan uji normalitas, peneliti menunjukkan koefisien regresi $b=0,55$ dan koefisien determinasi $R^{2}=0,32$ pada taraf signifikansi $p=0,00(p<0,05)$, sehingga secara signifikan dukungan sosial orang tua berpengaruh positif terhadap motivasi belajar intrinsik. Hasil uji regresi dukungan sosial orang tua dan motivasi belajar intrinsik terhadap

Tabel 2.

Hasil Uji Normalitas

\begin{tabular}{lcc}
\multicolumn{1}{c}{ Variabel } & Z-score & $p$ \\
\hline Dukungan Sosial Orang Tua (X) & 0,71 & $p>0,05$ \\
Motivasi Belajar Intrinsik (M) & 0,67 & $p>0,05$ \\
Prestasi Akademis (Y) & 0,79 & $p>0,05$ \\
\hline
\end{tabular}

Tabel 3.

Hasil Uji Linearitas

\begin{tabular}{lcc}
\multicolumn{1}{c}{ Variabel } & $\boldsymbol{F}$ & $p$ \\
\hline $\begin{array}{l}\text { Dukungan Sosial Orang Tua }(\mathrm{X}){ }^{*} \text { Motivasi Belajar } \\
\text { Intrinsik (M) }\end{array}$ & 1,573 & $p>0,05$ \\
$\begin{array}{l}\text { Dukungan Sosial Orang Tua }(\mathrm{X}) \\
\text { (Y) Prestasi Akademis }\end{array}$ & 1,435 & $p>0,05$ \\
$\begin{array}{l}\text { Motivasi Belajar Intrinsik (M) }{ }^{*} \text { Prestasi Akademis } \\
(\text { Y) }\end{array}$ & 2,427 & $p<0,01$ \\
\hline
\end{tabular}

melakukan uji regresi untuk melihat apakah setiap variabel yang terlibat memiliki hubungan linier. Tabel 3 menunjukkan bahwa setiap variabel memiliki hubungan linier sehingga uji hipotesis dapat dilakukan.

\section{Uji hipotesis}

Peneliti selanjutnya melakukan uji regresi dengan model tiga jalur (lihat Tabel 4). Hasil uji regresi dukungan sosial orang tua terhadap prestasi akademis siswa menunjukkan koefisien regresi $b=0,43$ dan koefisien determinasi $R^{2}=0,18$ pada taraf signifikansi $p=0,00(p<0,05)$, sehingga secara signifikan dukungan sosial orang tua berpengaruh positif terhadap prestasi akademis. Hasil uji regresi dukungan sosial orang tua terhadap motivasi belajar intrinsik prestasi akademis menunjukkan koefisien regresi $b(\mathrm{X})=0,16$ pada taraf signifikansi $p=0,12(p>0,05)$, koefisien regresi $b(\mathrm{M})=$ 0,47 pada taraf signifikansi $p=0,00(p<$ $0,05)$, dan koefisien determinasi $R^{2}=0,34$ pada taraf signifikansi $p=0,00(p<0,05)$. Ini menunjukkan bahwa terjadi full mediation pada regresi dukungan sosial orang tua dan motivasi belajar intrinsik terhadap prestasi akademis. 
Tabel 4.

Koefisien Uji Hipotesis

\begin{tabular}{llcc}
\multicolumn{1}{c}{ Variabel } & & $b$ & $\boldsymbol{R}^{2}$ \\
\hline $\begin{array}{l}\text { Jalur 1: Dukungan Sosial Orang Tua }(\mathrm{X}) \\
\text { Akademis }(\mathrm{Y})\end{array}$ & Prestasi & $0,55^{*}$ & $0,30^{*}$ \\
\hline $\begin{array}{l}\text { Jalur 2: Dukungan Sosial Orang Tua }(\mathrm{X}) \\
\text { Belajar Intrinsik (M) }\end{array}$ & Motivasi & $0,43^{*}$ & $0,18^{*}$ \\
\hline $\begin{array}{l}\text { Jalur 3: Dukungan Sosial Orang Tua (X) + Motivasi Belajar } \\
\text { Intrinsik (M) Prestasi Akademis (Y) }\end{array}$ & $\begin{array}{c}0,16(\mathrm{X}) \\
0,47^{*}(\mathrm{M})\end{array}$ & $0,34^{*}$ \\
\hline
\end{tabular}

Keterangan: ${ }^{*}=$ signifikan (signifikansi $\left.p=0,00(p<0,05)\right)$

\section{Diskusi}

Berdasarkan hasil uji regresi dukungan sosial orang tua terhadap prestasi akademis menunjukkan koefisien regresi $b$ $=0,43$ pada taraf signifikansi $p=0,00(p<$ $0,05)$, artinya secara signifikan dukungan sosial orang tua berpengaruh positif terhadap prestasi akademis. Hasil uji regresi dukungan sosial orang tua terhadap motivasi belajar intrinsik menunjukkan koefisien regresi $b=0,55$ pada taraf signifikansi $p=0,00(p<0,05)$, artinya secara signifikan dukungan sosial orang tua berpengaruh positif terhadap motivasi belajar intrinsik. Hasil uji regresi dukungan sosial orang tua dan motivasi belajar intrinsik terhadap prestasi akademis menunjukkan koefisien regresi $b$ $(X)=0,16$ pada taraf signifikansi $p=0,12(p$ $>0,05)$ dan koefisien regresi $b(\mathrm{M})=0,47$ pada taraf signifikansi $p=0,00(p<0,05)$. Ini menunjukkan bahwa terjadi full mediation pada regresi dukungan sosial orang tua dan motivasi belajar intrinsik terhadap prestasi akademis, atau dengan kata lain pengaruh dukungan sosial orang tua terhadap prestasi akademis hilang dan motivasi belajar intrinsik sepenuhnya memediasi pengaruh dukungan sosial orang tua terhadap prestasi akademis. Selain itu, koefisien regresi $b$ dapat menunjukkan pengaruh perubahan satuan pada suatu variabel terhadap perubahan satuan variabel lain. Ini berarti setiap peningkatan 1 satuan dukungan sosial orang tua akan meningkatkan 0,55 satuan motivasi belajar intrinsik, dan setiap peningkatan 1 satuan motivasi belajar intrinsik akan meningkatkan 0,47 satuan prestasi akademis.

Pengaruh dukungan sosial orang tua terhadap motivasi belajar intrinsik dan prestasi akademis maupun motivasi belajar intrinsik terhadap prestasi akademis telah cukup banyak diteliti, seperti penelitian Rahman (2014) yang menunjukkan dukungan sosial orang tua berpengaruh secara signifikan terhadap motivasi belajar dan prestasi akademis siswa-siswi. Penelitian Anjariah (2006) juga menunjukkan secara signifikan terdapat hubungan yang positif antara prestasi belajar anak di sekolah dengan dukungan sosial orang tua. Semakin orang tua ikut berpartisipasi dalam kegiatan anak, termasuk kegiatan akademik, maka semakin bagus pula prestasi anak dalam kegiatan tersebut. Selanjutnya, penelitian Ramida, Astuti \& Swaramarinda (2014) menunjukkan secara signifikan motivasi belajar intrinsik dan prestasi belajar memiliki hubungan yang positif. Semakin tinggi motivasi belajar intrinsik siswa maka semakin tinggi pula prestasi belajarnya. Berdasarkan uraian di atas dapat disimpulkan bahwa terdapat dukungan sosial orang tua berpengaruh positif terhadap prestasi akademis melalui mediasi motivasi belajar intrinsik. Semakin tinggi dukungan sosial orang tua dan motivasi belajar intrinsik maka 
semakin tinggi prestasi akademis, dan semakin rendah dukungan sosial orang tua dan motivasi belajar intrinsik maka semakin rendah prestasi akademis.

Maslow (dalam Feist \& Feist, 2008) berpendapat bahwa setiap manusia memiliki kebutuhan-kebutuhan yang akan berusaha ia penuhi. Kebutuhan ini dibagi menjadi dua, yaitu deficiency needs dan growth needs. Siswa yang deficiency needs-nya telah terpenuhi akan berusaha untuk memenuhi growth needs mereka. Salah satu contoh deficiency needs adalah dukungan sosial orang tua, sementara growth needs dapat ditunjukkan melalui kegiatan belajar dan berprestasi (Eggen \& Kauchak, 2010; Santrock, 2011; Slavin, 2006). Prestasi akademis siswa yang rendah seringkali diasosiasikan dengan kurangnya motivasi, sementara prestasi akademis yang tinggi diasosiasikan dengan motivasi yang juga tinggi dan pada umumnya diperoleh oleh siswa yang termotivasi secara intrinsik (Baranek, 1996). Siswa yang telah memperoleh dukungan sosial orang tua yang cukup akan cenderung termotivasi untuk belajar dan berprestasi sehingga motivasi belajar intrinsik dan prestasi akademis siswa dapat meningkat.

Grolnick, Friendly, dan Bellas (dalam Usher \& Kober, 2012) mengatakan bahwa keterlibatan orang tua yang aktif dalam pendidikan siswa dan penyediaan lingkungan belajar yang menstimulasi di rumah dapat membantu mengembangkan rasa kompeten, kontrol, ingin tahu, dan sikap positif mengenai hal-hal akademis. Knollman dan Wild (2007) menemukan bahwa motivasi intrinsik siswa lebih berkembang ketika orang tua memberikan kesempatan siswa untuk belajar dengan mandiri. Penelitian tersebut menunjukkan bahwa siswa menunjukkan personal enjoyment yang lebih tinggi ketika orang tua menghargai otonominya sebagai pembelajar. Salah satu bentuk stimulasi yang dapat diberikan orang tua adalah memberikan kesempatan bagi anak untuk mengajukan pertanyaan mengenai hal-hal yang terkait dengan mata pelajarannya dan menyediakan jawaban-jawaban bersifat positif terhadap keingintahuan anak (Gottfried et al., 2016). Hal ini akan menumbuhkan keingintahuan natural (personal curiosity) pada diri anak mengenai mata pelajaran yang dipelajarinya.

Dukungan sosial orang tua yang rendah dapat disebabkan oleh beberapa faktor, seperti SES (Status Sosial Ekonomi) dan anggapan orang tua terhadap kemampuan anak. Heckman (dalam Usher \& Kober, 2012) mengatakan bahwa orang tua dengan SES menengah ke bawah jarang berbicara dengan anak-anak mereka dan cenderung kurang terlibat dalam kegiatan sekolah anak. Usher \& Kober (2012) selanjutnya mengatakan bahwa anak-anak yang berasal dari keluarga dengan SES menengah ke bawah cenderung kurang memiliki kesempatan untuk mengembangkan kompetensi, kurang terdorong untuk menyukai belajar dan memahami pentingnya pendidikan, ataupun kurang mengembangkan hubungan sosial yang mendukung dan menghargai prestasi anak-anak tersebut. Dweck (dalam Usher \& Kober, 2012) juga mengatakan bahwa memuji tingkat inteligensi anak daripada usaha dan kemampuan mereka dapat mengarahkan anak untuk menghindari tantangan dan takut menghadapi kegagalan.

Penelitian yang dilakukan oleh Fan dan Williams (2010) menemukan bahwa bentuk dukungan sosial yang diberikan orang tua memiliki peran terhadap pembentukan motivasi intrinsik siswa secara berbeda-beda, tergantung pada mata pelajarannya. Ketika orang tua memberikan dukungan bersifat informasional seperti saran mengenai bagaimana sebaiknya anak meningkatkan 
prestasinya, peningkatan motivasi intrinsik ditemukan pada pelajaran bahasa (Fan \& Williams, 2010). Penelitian yang sama juga menemukan bahwa ketika bentuk dukungan orang tua lebih bersifat instrumental (misal: peraturan), motivasi intrinsik yang terbentuk ditemukan pada pelajaran bahasa dan matematika. Karena dalam penelitian ini tes sumatif dianalisis sebagai skor total, akan menarik apabila penelitian selanjutnya menganalisis hasil skor sesuai dengan mata pelajaran masing-masing.

Penelitian-penelitian sebelumnya telah menjelaskan bahwa siswa dengan orientasi motivasi belajar intrinsik akan berfungsi lebih efektif dalam kegiatan pembelajaran (Dev, 1997). Hal ini disebabkan karena siswa lebih menikmati proses belajar, mengembangkan minat terhadap topik-topik yang dipelajarinya, serta memiliki kepuasan internal ketika ia berhasil menguasai sebuah tugas. Ryan dan Deci (2002) menyatakan bahwa motivasi intrinsik melambangkan selfdetermination. Ketika individu memiliki self-determination, ia akan lebih siap dalam menghadapi tantangan-tantangan tugas di hadapannya dan memiliki kesempatan yang lebih besar untuk sukses.

Berdasarkan hasil analisis mediasi Kim (2016) diperoleh koefisien determinasi dukungan sosial orang tua terhadap prestasi akademis $R^{2}=0,18$ pada taraf signifikansi $p=0,00(p<0,05)$; koefisien determinasi dukungan sosial orang tua terhadap motivasi belajar intrinsik $R^{2}=0,30$ pada taraf signifikansi $p$ $=0,00(p<0,05)$; dan koefisien determinasi dukungan sosial orang tua dan motivasi belajar intrinsik terhadap prestasi akademis menunjukkan $R^{2}=0,34$ pada taraf signifikansi $p=0,00(p<0,05) . R^{2}$ atau koefisien determinasi menunjukkan sumbangan efektif suatu variabel terhadap variabel lain atau persentase suatu variabel dalam menjelaskan keragaman pada variabel lain. Dukungan sosial orang tua hanya mampu menjelaskan keragaman pada prestasi akademis sebesar 18,70\%. Dukungan sosial orang tua mampu menjelaskan keragaman pada motivasi belajar intrinsik sebesar $30,60 \%$. Dukungan sosial orang tua dan motivasi belajar intrinsik mampu menjelaskan keragaman pada prestasi akademis sebesar 34,30\%.

Penelitian ini juga memiliki beberapa keterbatasan. Pertama, keterbatasan waktu dan biaya membuat subjek yang digunakan dalam penelitian ini hanya siswa kelas 8 di tiga SMP Negeri di Kota Yogyakarta. Untuk mengambil kesimpulan yang dapat digeneralisasi lebih luas maka perlu dilakukan penelitian yang melibatkan subjek atau jumlah sekolah yang lebih banyak. Kedua, pengumpulan data dalam penelitian ini hanya menggunakan skala dan hasil tes sumatif sehingga tidak menutup kemungkinan terjadi bias dan pengaruh sosial yang tinggi. Terakhir, masih ada faktor-faktor di luar dukungan sosial orang tua dan motivasi belajar intrinsik yang berpengaruh dan berhubungan dengan prestasi akademis yang belum diteliti.

\section{Kesimpulan}

Berdasarkan hasil penelitian yang telah dibahas pada subbab pembahasan, dapat disimpulkan secara signifikan dukungan sosial orang tua berpengaruh positif terhadap prestasi akademis melalui mediasi motivasi belajar intrinsik. Semakin tinggi dukungan sosial orang tua dan motivasi belajar intrinsik siswa maka semakin tinggi prestasi akademis siswa, dan semakin rendah dukungan sosial orang tua dan motivasi belajar intrinsik siswa maka semakin rendah prestasi akademis siswa. Namun, pengaruh dukungan sosial orang tua terhadap 
prestasi akademis hilang ketika dimediasi oleh motivasi belajar intrinsik. Setiap peningkatan 1 satuan dukungan sosial orang tua akan meningkatkan 0,55 satuan motivasi belajar intrinsik, dan setiap peningkatan 1 satuan motivasi belajar intrinsik siswa akan meningkatkan 0,47 satuan prestasi akademis. Penelitian ini juga menemukan dukungan sosial orang tua, motivasi belajar intrinsik, dan prestasi akademis sebagian besar subjek dalam penelitian ini berada pada kategori sedang sehingga perlu ditingkatkan.

\section{Saran}

Pemerintah dan sekolah sebaiknya menggunakan hasil penelitian ini untuk merencanakan program peningkatan partisipasi orang tua dalam pendidikan dan kegiatan siswa di sekolah agar motivasi belajar intrinsik dan prestasi akademis siswa dapat meningkat. Selain itu, melalui program tersebut pemerintah dan sekolah mendorong orang tua untuk bekerja sama dengan sekolah dalam menyediakan lingkungan belajar yang menstimulasi di rumah dan menghargai usaha dan kemampuan siswa dalam belajar di rumah dan di sekolah. Peneliti selanjutnya disarankan untuk melibatkan lebih banyak subjek seperti siswa kelas 7 dan 9 atau jumlah sekolah yang lebih banyak agar hasil penelitian dapat digeneralisasi lebih luas. Selain itu, peneliti selanjutnya disarankan untuk menggunakan instrumen penelitian yang lebih beragam sehingga bias dan pengaruh sosial lebih dapat ditekan. Terakhir, peneliti selanjutnya disarankan untuk menambahkan faktor-faktor di luar dukungan sosial orang tua dan motivasi belajar intrinsik untuk digunakan dalam meneliti variabel apa saja yang dapat memengaruhi prestasi akademis.

\section{Kepustakaan}

Anjariah, S. (2006). Prestasi belajar siswa ditinjau dari dukungan sosial orang tua. Jurnal Psikologi, 2(1), 1-5.

Azwar, S. (2014). Tes prestasi: Fungsi dan pengembangan pengukuran prestasi belajar (Edisi kedua). Yogyakarta: Pustaka Pelajar.

Azwar, S. (2017). Pengantar psikologi inteligensi. Yogyakarta: Pustaka Pelajar.

Baranek, L. (1996). The effect of rewards and motivation on student achievement (Laporan tidak dipublikasikan). Allendale: Graduate Faculty of Grand Valley State University.

Bean, R., Bush, K., McKenry, O., \& Wilson, S. (2003). The impact of parental support, behavioral control, and psychological control on the academic achievement and selfesteem of African American and European American adolescents. Journal of Adolescent Reserach, 18(5), 523-541.

doi: $\underline{10.1177 \% 2 F 0743558403255070}$

Cutrona, C., \& Russell, D. (1987). The provisions of social relatonships and adaptation to stress. In W. H. Jones \& D. Perlman (Eds.), Advances in personal relationships (pp. 37-67). Stamford, CT: JAI Press.

Desforges, C., \& Abouchaar, A. (2003). The impact of parental involvement, parental support and family education on pupil achievement and adjustment: A literature review. DFES Research Report.

Dev, P. C. (1997). Intrinsic motivation and academic achievement: What does their relationship imply for the classroom teacher? Remedial and Special Education, 18(1), 12-19. doi: $\underline{10.1177 / 074193259701800104}$ 
Eggen, P., \& Kauchak, D. (2010). Educational psychology: Windows on classroom (Edisi kedelapan). New Jersey: Merill.

Fan, W. \& Williams, C. M. (2010). The effects of parental involvement on students' academic self-efficacy, engagement and intrinsic motivation. Educational Psychology, 30(1), 53-74. doi: 10.1080/01443410903353302

Feist, J. \& Gregory, J. F. (2008). Theories of personality (Edisi Ketujuh). New York: McGraw-Hill.

Gordon, A. (2011). Assessing social support in children: Development and initial validation of the social support questionnaire for children (Disertasi tidak dipublikasikan). Louisiana: Graduate School Faculty of Louisiana State University and Agriculture and Mechanical College.

Gottfried, A. E., Preston, K. S. J., Gottfried, A. W., Oliver, P. H., Delany, D. E., \& Ibrahim, S. M. (2016). Pathways from parental stimulation of children's curiosity to high school science course accomplishments and science career interest and skill. International Journal of Science Education, 38(12), 1972-1995. doi: $\underline{10.1080 / 09500693.2016 .1220690}$

International Association for the Evaluation of Educational Achievement (IEA). (2016a). TIMSS 2015 international results in mathematics. Diakses melalui http://timssandpirls.bc.edu/timss201

5/international-results/timss2015/mathematics/studentachievement/distribution-ofmathematics-achievement/ (pada 21 Juli 2017)

International Association for the Evaluation of Educational Achievement (IEA). (2016b). TIMSS 2015 international results in science.
Diakses melalui http://timssandpirls.bc.edu/timss201 5/international-results/timss2015/science/studentachievement/distribution-of-scienceachievement (pada 21 Juli 2017)

Kim, B. (2016). Introduction to mediation analysis. Diakses melalui http://data.library.virginia.edu/intro duction-to-mediation-analysis (25 Juli 2017)

Khosnam, A., Ghamari, M., \& Gendavi, A. (2013). The relationship between intrinsic motivation and happiness with academic achievement in high school students. International Journal of Academic Research in Business and Social Sciences, 3(11), 330-336. doi: 10.6007/IJARBSS/v3-i11/342

Knollman, M. \& Wild, E. (2007). Quality of parental support and students' emotions during homework: Moderating effects of students' motivational orientations. European Journal of Psychology of Education, 22(1), 63-76. doi: $\underline{10.1007 / B F 03173689}$

Li, L. (2012). A study of the attitude, selfefficacy, effort, and academic achievement of university students towards research methods and statistics. Discovery-SS E-Journal, 1, 154-183.

Organisation for Economic Co-operation Development (OECD). (2016). PISA 2015 results in focus. Paris: Organisation for Economic Cooperation Development.

Phye, G. (1997). Handbook of classroom assessment: Learning, achievement, and adjustment. San Diego: Academic Press.

Rahman, M. (2014). Pengaruh dukungan orang tua dan fasilitas belajar di sekolah terhadap prestasi belajar ekonomi melalui motivasi belajar siswa kelas VIII SMP Negeri 2 
Ungaran. Economic Education Analysis Journal, 3(2), 410-417.

Rahmi, E. (2011). Pengaruh dukungan orang tua dan motivasi belajar terhadap prestasi belajar musik pada remaja (Skripsi tidak dipublikasikan). Universitas Islam Negeri Syarif Hidayatullah, Jakarta.

Ramida, G., Widyastuti, U., \& Swaramarinda, D. (2014). Hubungan antara motivasi intrinsik dengan prestasi belajar siswa kelas $X$ pada SMK Nurul Iman Jakarta. Jurnal Pendidikan Ekonomi dan Bisnis, 2(1), 2302-2663. doi: 10.21009/JPEB.002.1.6

Ryan, R., \& Deci, E. L. (2000). Intrinsic and extrinsic motivations: Classic definitions and new directions. Contemporary Educational Psychology, 25, 54-67. doi: $10.1006 /$ ceps.1999.1020

Ryan, R. M., \& Deci, E. L. (2002). Overview of self-determination theory: An organismic dialectical perspective. In E. L. Deci \& R. M. Ryan (Eds.), Handbook of selfdetermination research (pp. 3-33). Rochester, NJ: University of Rochester Press.

Santrock, J. (2011). Educational psychology (Edisi kelima). New York: McGrawHill.
SIAP PPDB Online. (2014). Statistik PPDB SMP jalur reguler kota Yogyakarta periode 2014/2015. Diakses melalui https://arsip.siap-

ppdb.com/2014/yogya (pada 10 Maret 2017)

SIAP PPDB Online. (2015). Statistik PPDB SMP jalur reguler kota Yogyakarta periode 2015/2016. Diakses melalui https://arsip.siapppdb.com/2015/yogya (pada 10 Maret 2017)

SIAP PPDB Online. (2016). Statistik PPDB SMP jalur reguler kota Yogyakarta periode 2016/2017. Diakses melalui https://yogya.siap-ppdb.com (pada 10 Maret 2017)

Slavin, R. (2006). Educational psychology: Theory and practice (Edisi kedelapan). Boston: Pearson Education.

Usher, A., \& Kober, N. (2012). What roles do parent involvement, family background, and culture play in student motivation? Washington, DC: Center on Education Policy.

VandenBos, G. (2015). APA dictionary of psychology (Edisi kedelapan). Washington, DC: American Psychological Association. 